\title{
The impact of globalization on transport investment
}

\author{
Florin Dobre ${ }^{1}$, Valentin Pauna ${ }^{2}$, Alexandru Cristian Vasilescu ${ }^{3}$, and Ovidiu Andrei Cristian \\ Buzoianu $^{4 *}$ \\ ${ }^{1}$ Bucharest University of Economic Studies, Lecturer PhD, Bucharest, Romania \\ ${ }^{2}$ Bucharest University of Economic Studies, Phd Student, Bucharest, Romania \\ ${ }^{3}$ Bucharest Polytechnic University, Phd Student, Bucharest, Romania \\ ${ }^{4}$ Bucharest University of Economic Studies, Assistant Prof. Bucharest, Romania
}

\begin{abstract}
Research background: The economic impact of investing in new transport capacity or improving existing ones is complex and often indirect. Loans for infrastructure are often needed, but they cannot create sufficient conditions for economic growth. Investments in transport infrastructure require public funding. An assessment of their cost-effectiveness is needed to ensure a reasonable and acceptable allocation. Relevant economic, environmental and social effects must be taken into account. There is a growing concern in the transport sector about decisions on the development of the transport system and the effects of scale and externalities they produce. Planners and decision-makers need to know more about the wider economic impact of individual infrastructure projects and transport policies in general.

Purpose of the article: This paper aims to present the most important theoretical and practical aspects of the importance of transport investment worldwide, at European level and Romania. Investments in transport infrastructure will not improve the economic vitality of a region unless it has sufficient economic capacity and employment, land use and economic development policies.

Methods: This article starts from the hypothesis of the influence of globalization on the development of transport systems in general and applies as a case study on Romania. The paper was based on the analysis of transport legislation, as well as data sets for the period 2011-2019, to observe the gradual development of all types of transport.

Findings \& Value added: Following these researches, the link between globalization and investments in transport systems was found by emphasizing accessibility to new infrastructures, new horizons and development plans for the main types of transport, which is a key element in economic activity. The main results were disseminated throughout the article and it adds value through the analysis created at global and regional level (at European level) and the interpretation of statistical data related to transport investments.
\end{abstract}

Keywords: economy; investment;transport; development

JEL Classification: $L 91 ; 018$

\footnotetext{
* Corresponding author: buzoianuovidiu@yahoo.com
} 


\section{Introduction}

Transport connects people, businesses and resources (Bran et al., 2018). Transport demand is the result of economic activities of companies, households and individuals (Abrell, 2009). Changes in the transport system, in turn, have effects on economic development, which can be defined by the company's strategic economic objectives and objectives in terms of, for example, income, jobs, competitiveness, commercial activity, property values, affability, tax revenues, equity (Burlacu, 2018). These objectives have local, regional and national dimensions (Sarbu et al., 2021). Investment decisions are key decisions in any long-term development strategy (Stoica et al., 2014). The main reason for using economic resources today is to obtain economic benefits in the future (Bodislav et al., 2021). Decisions on transport infrastructure are taken by public agencies and governments and are expected to support the public good (Burlacu and Stoica, 2012).

Therefore, project evaluation is used to investigate and reason the consequences of decisions to help decision makers make informed and rational choices (Brida, 2019). Transport authorities in most countries have a long tradition of using the principles of practical cost-benefit analysis (CBA) in evaluating transport projects (Radulescu et al, 2020).

The theoretical framework for such an analysis is broad and therefore there are international, European (EU) and nationally harmonized guidelines for the evaluation of transport projects (Bran et al., 2018). The CBA provides decision-making tools to analyze the primary impact of transport project proposals (Profiroiu et al., 2020).

There is a growing awareness in the transport sector that decisions on transport system development are associated with scale effects and externalities that produce more than transport cost savings (Antras, 2017). There may be greater economic effects as a result of funds invested in the region and reduced transport costs . These benefits may include, for example, job creation, increased productivity and labor availability, changes in land and property values. The concern in this regard is that without proper recognition of the wider impact of the transport decision-making framework, decisions can lead to the undesirable allocation of investment funds (Radulescu et al., 2019).

As investment in transport affects growth and well-being, it is important in decisionmaking to have a broad view of the economic impact (Littman, 2019). The direct, indirect and induced effects together ensure the total economic impact of transport investments (Litra and Burlacu, 2014).

The direct economic impact of a transport investment includes investment and maintenance costs, transport operators' operating costs and business travel and freight time costs (Coulibaly, 2018). In addition, the costs of traffic accidents and pollution include potentially relevant cost elements. The main economic impact of improving transport is the reduction of time for freight drivers and business travelers.

\section{Methods}

This article starts from the hypothesis of the influence of globalization on the development of transport systems in general and applies as a case study on Romania. The paper was based on the analysis of transport legislation, as well as data sets for the period 2011-2019, to observe the gradual development of all types of transport. 


\section{Results and discussion}

\subsection{The effects of transport investments on economic development}

In addition to the direct and indirect effects of an investment in transport and the improved functioning of the system, changes in the transport environment can lead to changes in regional economic structures and exchanges of economic activities between regions in the long run (Shantayanan, 2020).

The economic impact of a transport investment is largely based on the effects of the investment on accessibility. Faster train connections and increased supply and quality of transport services reduce the costs of personal mobility and freight transport. This makes trade in goods and services more profitable and communication and interaction between people easier. Improving accessibility allows businesses to strengthen their geographic markets (if the size of the market area depends on accessibility). This can increase competition in certain locations, but at the same time allow for deeper specialization, which increases productivity.

Accessibility improvements can also make labor market areas larger, as job centers can be contacted from greater distances within a reasonable time (Meersman, 2017) This tends to increase employment and lead to an improvement in the balance between labor supply and demand (Listiono, 2018). The more polarized and specialized labor markets are, the better it is to develop labor market areas.

Significant improvements in accessibility can drive a strong growth momentum for a region (Ferrell, 2020). This is possible especially if new connections are created or two or more modes of transport (eg high-speed railways and motorways) are developed simultaneously for a region with growth potential but with a previously underdeveloped transport system (Bank World Cup 2009). In this case, accessibility improvements act as a catalyst for economic growth, but in the long run, the larger size allows the region to create congestion benefits for businesses and households, which can lead to further growth.

The benefits of localization are based on the large size of a particular sector in the region (Graham, 2012). This makes it possible to exploit the benefits on a large scale in the input and logistics markets and supports the creation and distribution of innovations in the region. The benefits of urbanization are based on the size and great diversification of the entire urban region (Kraemer, 2005). For companies, urbanization means more competition, wider variations of goods, more opportunities for specialization and cooperation. For households, urbanization means a wider range of consumption possibilities. For labor markets, the large size of the urban region means better matching of labor supply and demand. An important factor is the possibility to spread knowledge, innovations and technologies between sectors.

Figure 1 shows that the intensity of business communication between companies in different regions depends both on the characteristics of the transmission system and on the structure and specialization of the industry.

The density and efficiency of the transport system determine the accessibility of other regions. On the other hand, the specialized industry based on the competitive advantages of the regions influences the potential of business communication between companies from different regions. In general, good accessibility of a region tends to attract companies with large market areas and a great need for business communication in a large geographical area. 


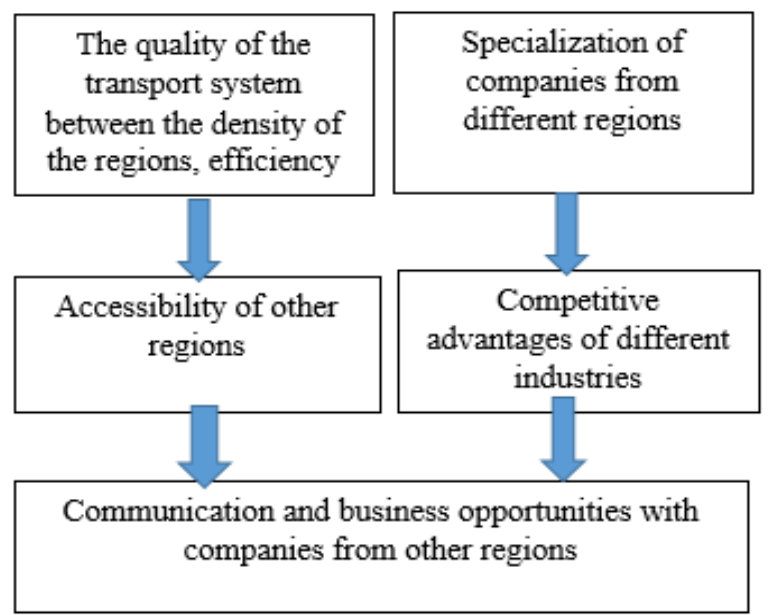

Figure 1. The process for improving the market share of companies.

Source: after Kraemer K. L., 2005

The intensity of business communication between companies in different regions depends both on the characteristics of the transport system and on the structure and specialization of the industry (Tereshina, 2020). The density and efficiency of the transport system determine the accessibility of other regions.

On the other hand, the industrial specialization based on the advantages of the competitiveness of the regions influences the potential of business communication between the companies from different regions. In general, the good accessibility of a region tends to attract companies with large market areas and the need for business communication in a wide geographical area.

\subsection{Impact on land use and property value}

In urban areas, investment in transport can affect land and property use in the long run. The potential for change lies primarily in the vicinity of new or improved transport links, such as railway stations (railway investments), road intersections (road investments) and airports (airport investments) (Popescu et al., 2018), but the effects can also influence a wider area or the entire urban region, if the investments act as a catalyst for a process based on agglomeration effects (Varnavskii, 2020). Next, we focus on the potential land use effects of railway investments that improve passenger transport.

Accessibility improvements caused by railway investments make locations near old or new railway stations more attractive to businesses and households (Saidi, 2018).

Companies have improved access to the railways, especially in other regions, but also in the same region. This makes contacts between the business environment and businesses easier to improve the accessibility of communication for companies. It also improves the possibility for companies to get a job due to faster and better road transport in a larger area. The increase in passenger flows in the vicinity of the stations makes the location more attractive for retail and other household services. Improving transport accessibility and changing jobs and services can also make housing more attractive (Stoica et al., 2013).

These accessibility improvements influence the level of rental firms that are willing to pay in the immediate vicinity of improved accessibility (Vincze, 2008). 
This leads to higher rents and prices of old and new commercial space. It is further capitalized on the value of the land in the area. These price changes also create pressure to change land use in two ways. First, increasing the value of land leads to a demand for increased density in the area. Second, the industrial structure in the area tends to change. Old activities, such as manufacturing and storage, tend to move to new locations, while they are being replaced by industries with improved accessibility, such as business services, retail and other household services. .

The increased level of land value and the change in the distribution of land value create pressure for planning. An increase in land efficiency is created (larger buildings and less vacant space). In addition, the area where the construction is profitable becomes larger.

However, planning rules restrict the implementation of land use changes. There may be political reasons to limit construction efficiency and access to new land use in the area (Rohacs, 2020). Long-term changes in land use as a consequence of a transport investment are at least partially realized, at the cost of other locations in the region (Singh, 2021). When the demand for land use in one location increases, it normally decreases, at least marginally, in other locations, respectively. However, it is not a zero-sum game if land use in the region becomes more efficient, increasing the productivity of companies that benefit from changes in land use.

\subsection{Analysis of transport investments in Romania}

The transport network in Romania is quite varied, our country being from this point of view at an acceptable level compared to other countries. The transports are urban inside the localities but also interurban (Pencea, 2009).

According to official statistics on long-distance and international traffic, in 2019 a total number of $414,525,000$ passengers were registered, of which approximately $77 \%$ traveled by road, the rest choosing the train as a means of transport.

In the coming years, based on increased globalization and funds received, major investments in transport infrastructure are expected through the modernization of national roads and local interest, but also in the construction of highways.

It also aims to modernize the railways and increase the average speed, which is currently at a low level compared to other European countries, but also the construction of new railways, such as Vâlcele-Râmnicu Vâlcea located on the IV transport corridor European. Other measures to be taken for the modernization of the Romanian infrastructure are the construction of new airports (Ghimbav-Brașov, Galați-Brăila, etc.) and the increase of the existing ones. In the field of naval transport, the increase of the traffic on the Danube will be pursued. 
Romania has railway connections with all neighboring countries. If for Hungary, Serbia and Bulgaria the crossing of the border does not pose any problem, in the case of Ukraine and the Republic of Moldova the gauge change is made from $1435 \mathrm{~mm}$ to $1524 \mathrm{~mm}$. The only line that crosses a border and is electrified is between Curtici and Leucuşhaz.

As of 31.12 .2019 , public roads totaled $83,386 \mathrm{~km}$, of which 17,552 km (20.1\%) national roads, $36,221 \mathrm{~km}(42.8 \%)$ county roads and $31,613 \mathrm{~km}(37.1 \%)$, communal roads. However, the investments made do not guarantee drivers a carefree trip, because half of these rebuilt areas are deficient and have exceeded their service life. Romania ranks 120th in terms of road quality, in a top made by the World Economic Forum (GEF).

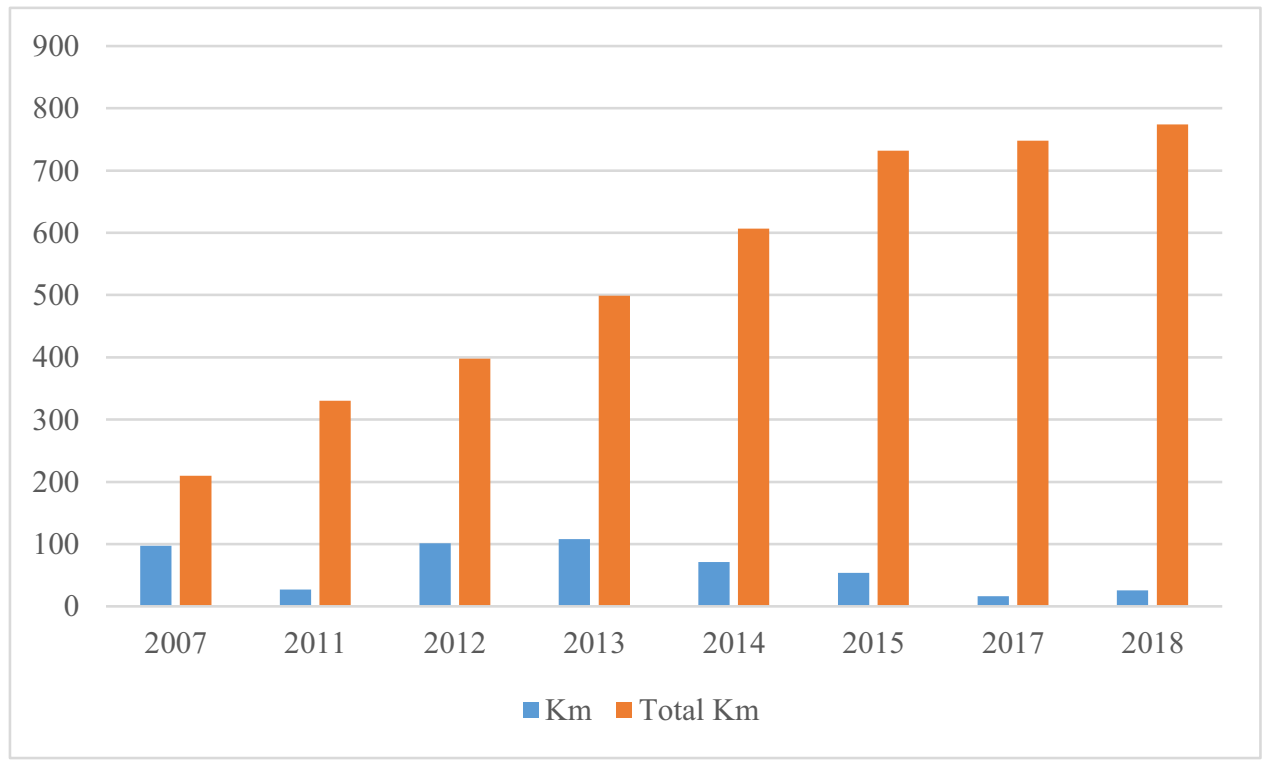

Figure 2. Electrified railways infrastructure.

Source: INSSE Data

In August 2019, in Romania there were $600 \mathrm{~km}$ of express roads, but their main problem is the bottleneck that occurs near cities, in the absence of two-lane bypasses. Among the existing express roads are the routes Bucharest-Giurgiu, Bucharest-Ploiești West-Comarnic Beltway, Constanța-Mangalia, Brașov-Codlea, Cluj-Turda, Bucharest-Urziceni-BuzăuFocșani-Bacău-Roman-Iași and Craiova-Filiași.

In 2018, the air traffic reached, in value, approximately 700 million euros and 10.1 million passengers, for the 17 airports in Romania.

Romanian river transport is still at a very low level (below a percentage) but with high growth potential due to navigable rivers and the Danube river.

Romanian waterways are used more for the export or import of goods than for the transport of goods within the country.

The freight transport market is dominated by road transport, which covered $79.3 \%$ in 2019 , followed by rail transport $-21.9 \%$, river $-6.8 \%$, by pipeline $-2.9 \%$, sea $-0.2 \%$ and air $-0.01 \%$. Road freight transport is the busiest branch of this market, with 12,000 operators with a total of 105,500 employees. 


\section{Discussion and Conclusion}

It has been shown that there may be a tool that is relatively simple to use, but provides results that are based on comprehensive CGE modeling. This can be seen as a promising start for a wider use of advanced economic impact modeling in the transport sector.

However, the results of this project are only applicable to fairly large railway investments, and the results are calculated and presented on a spatial resource, which is quite crude.

Further efforts are needed to define similar instruments for investment in roads and other forms of transport improvement and to delimit the spatial resolution of instruments.

The objectives are to develop concepts and mechanisms for broader economic impacts of investment in transport and to develop a tool for assessing these impacts. This report on the economic impact of transport investments is the first result of the project.

Investments in transport capital reduce transport and production costs, thus contributing to long-term economic growth and productivity. Investment costs as such have several immediate economic effects during the construction phase. The ways in which new or improved transport capacities influence the economic system are complex and often indirect.

Improving transport infrastructure will not improve the economic vitality of a region unless there are other positive factors. The characteristics of the affected economy as well as land use and other policies must be receptive and supportive of investment and its impact.

The transport sector has a long tradition of using the principles of practical cost-benefit analysis in the evaluation of transport projects that analyze the primary impact of transport project proposals. However, there is a growing need to learn more about the wider economic impact of individual infrastructure projects and transport policies in general. To date, the only general and widespread guideline for assessing higher economic impacts is that such impacts may exist, but they should not be added to the basic cost-benefit calculation to avoid double counting.

It has been shown that there may be a tool that is relatively simple to use, but provides results that are based on comprehensive CGE modeling. This can be considered a promising start for the use of advanced economic impact modeling in the transport sector.

The standard evaluation of transport projects (CBA) is the basic tool for estimating the direct economic impact of a transport investment. This is necessary, but not enough to estimate the wider economic impact. There is a growing need to learn more about the wider economic impact of individual infrastructure projects and transport policies in general.

There are several analytical techniques for estimating these impacts of economic development, ranging from simple case studies and surveys to modeling complex economic simulation. However, it is impossible to name a single analytical tool that is equally useful for all information needs in planning and decision making.

The opportunity to develop an intermodal transport strategy in Romania is justified by the following considerations:

- fits into the context of policies to reduce the impact of transport on the environment and to substantiate a sustainable development strategy, striking a balance between economic growth and environmental protection,

- intermodal transport is considered a safe alternative for the future, as it best meets both the acute requirements for the decongestion of national roads and the growing requirements of transport beneficiaries in terms of range and quality of services,

- there is no distortion of competition between the main players on the freight transport market in Romania that would prejudice the public interest, the same rules being applied non-discriminatory to all transport operators,

- intermodal transport has the capacity to contribute to the relaunch of freight traffic in Romania and to reduce the effects of the economic crisis,

- Also, the realization and implementation of the intermodal transport strategy in

- Romania has a special importance from the following perspectives: 
- Increasing Romania's attractiveness for international trade activities by ensuring facilities for the intermodal exchange of goods that would attract both the "assembly package" and the "CEE package",

- Supporting the development of logistical and efficient transport "green corridors",

- Efficient use of existing infrastructure for freight transport by attracting freight flows from the road sector to the railway and naval sectors,

- Improving economic cooperation at regional, national and international level by creating distribution and freight exchange poles between long-distance and local / regional transport systems,

- Solving the problems related to the high transport costs of the economic operators and improving the access of the Romanian goods on the regional, national and international markets,

- Creating new jobs at local and regional level.

\section{Acknowledgement}

Thanks to the team for their help in writing this article. I would like to thank the National Institute of Statistics and Banking analyzed for their assistance with the statistics used in this report. I would like to express my deep gratitude to my colleagues for their continued encouragement, critical analysis of this article, and guidance.

\section{References}

1. Abrell, J. (2009). Transport under Emission Trading - A Computable General Equilibrium Assessment, Disertation, University of Dresden, Routledge.

2. Antras, P., De Gortari A., \& Itskhoki O. (2017). Globalization, ineaquality and welfare. Journal of International Economics, 108, 387-412.

3. Bodislav, D. A., Burlacu, S., Rădulescu, C. V., \& Gombos, S. P. (2021). Using a hybid economic indicator (BADEM) to evaluate the retail sector (R5N) and consumption. In: R. Pamfilie, V. Dinu, L. Tăchiciu, D. Pleșea, C. Vasiliu eds. (2021). 7th BASIQ International Conference on New Trends in Sustainable Business and Consumption, (pp. 34-42).

4. Bran, F., Burlacu, S., \& Alpopi, C. (2018). Urban transport of passengers in large urban agglomerations and sustainable development. experience of Bucharest municipality in Romania. Proceedings of 6th International Conference on Sustainable Development, The International Conference on Sustainable Development, (pp. 265-267).

5. Bran, F., Burlacu, S., \& Alpopi, C. (2018). Urban transport of passengers in large urban agglomerations and sustainable development. experience of Bucharest municipality in Romania. European Journal of Sustainable Development, 17(3), 2018, 265-273.

6. Brida, J. G., Lanzilotta, B., \& Pizzolon F. (2019). The nonlinear relationship between air transport development and economic growth: The cases of Chile and Uruguay. World Review of Intermodal Transportation Research, 8(4), 320-337.

7. Burlacu, S. \& Stoica, A. (2012). Analysis of freight transport on the street network of Bucharest. Quality - Access to Success (Calitatea - Acces la succes), S1(13), 66-69.

8. Burlacu, S., \& Stoica, A. (2012). Modern in public transport. Quality - Access to Success (Calitatea - Acces la succes), S1(13), 70-73. 
9. Burlacu, S. (2018). Ways to streamline the internal and external communication in the RATB. Economics, Management, and Financial Markets, 13(3), 234-240.

10. Coulibaly, S. K., \& Mekongcho T. M. (2018). Economic globalization, entrepreneurship, and development. Technological Forecasting and Social Change, 127, 271-280.

11. Ferrell, W., Ellis, K., Kaminsky, P., \& Rainwater, C. (2020). Horizontal collaboration: opportunities for improved logistics planning. International Journal of Production Research, 58(14), 4267-4284.

12. Graham, D. (2012). Wider economic benefits of transport investment and the role of agglomeration. A slide presentation. Imperial college London. Guide to Quantifying the Economic Impacts of Federal Investments in Large-Scale Freight Transportation Projects, Cambridge Systematics, Inc., Economic Development Research Group, Inc.

13. Kraemer, K. L., Gibbs, J., \& Dedrick, J. (2005). Impacts of globalization on ecommerce use and firm perormance: A cross-country investigation. The Information Society, 21(5), 323-340.

14. Listiono, L. (2018). The relationship between transport, economic growth and environmental degradation for ninety countries. Journal of Environment and Sustainability, 2(1), 11-23.

15. Litra, M., \& Burlacu, S. (2014). Management regulatory liberalization of the public service contracts in the rail industry. Administratie si Management Public, (22), 73.

16. Littman, T. (2019). Evaluating Transportation Economic Development Impacts.

17. Meersman, H., \& Nazemzadeh, M. (2017). The contribution of transport infrastructure to economic activity: The case of Belgium. Case Studies on Transport Policy, 5(2), 316-324.

18. Pencea, R. (2009). Dezvoltarea transporturilor, soluţie pentru creşterea competitivităţii şi modernizarea economiei româneşti. Revista de Transport şi Logistică, 35 .

19. Popescu, M. L., Dobrea, C. R., \& Burlacu, S. (2018). Inconsistency in natural resources management and managerial dimension in economic management. Proceedings of the 14th Administration and Public Management International Conference "Human Resources Management and Public Organizational Performance".

20. Profiroiu, C.-M., Rădulescu, C.-V., Burlacu, S., \& Guţu, C. (2020). Changes and trends in the development of the world economy. Culegere de articole ştiintifice ale Conferinţei Ştiinţific Internaţional "Competitivitate şi Inovare în economia cunoaşterii".

21. Radulescu, C. V., Bran, F., \& Burlacu, S. (2019). Strategic options for managing sustainable business. MIC 2019: Managing Geostrategic Issues; Proceedings of the Joint International Conference.

22. Radulescu, C. V., Bran, F., Bodislav, D. A., \& Burlacu, S. (2020). The sustainability paradigm of value and entropic approach of economic systems in the ideas of Paul Bran. In: R. Pamfilie, V. Dinu, L. Tăchiciu, D. Pleșea, C. Vasiliu eds. 6th BASIQ International Conference on New Trends in Sustainable Business and Consumption, (pp. 222-227).

23. Rohacs, J., \& Rohacs, D. (2020). Total impact evaluation of transportation systems. Transport, 35(2), 193-202.

24. Saidi, S., Shahbaz, M., \& Akhtar, P. (2018). The long-run relationships between transport energy consumption, transport infrastructure, and economic growth in MENA countries. Transportation Research Part A: Policy and Practice, 111, 78-9 5 . 
25. Sarbu, R., Alpopi, C., Burlacu, S., \& Diaconu, S. (2021). Sustainable urban development in the context of globalization and the health crisis caused by the covid19 pandemic. SHS Web of Conferences, 92.

26. Shantayanan, D. (2020). Has globalization gone too far-or not far enough? Georgetown Journal of International Affairs, 21, 114-119.

27. Singh, A., Gurtu, A. \& Singh, R. K. (2021). Selection of sustainable transport system: a case study. Management of Environmental Quality, 32(1), 100-113.

28. Stoica, A., Burlacu, S., \& Stoica, S. A. (2014). Studiul evoluţiei cererii de transport în zona adiacentă intersectiei Iuliu Maniu-Virtuții, comparativ cu intersecția Iuliu Maniu - B-dul Geniului (Leu). Analele Universităţii Bucureşti - Seria Ştiinţe Administrative, $1(1)$.

29. Tereshina, N. P., Podsorin, V. A., \& Ovsyannikova E. N. (2020). Development of transport infrastructure in the context of changing economic conditions. Journal of Transport, 3, 6-9.

30. Varnavskii, V. G. (2020). Global transport \& logistics infrastructure. World Economy and International Relations, 64(1), 5-14.

31. Vincze, M. (2008). Economia Europei. Aspecte teoretice și practice ale integrării economice europene (Europa Gazdasagtana. Az europai gazdasagi integracio elmeleti es gyakorlati kerdesei), Presa Universitară Clujeană, Cluj Napoca. 